\title{
Research on Talent Internationalization Cultivation Mode of Agricultural Universities-Illustrated by the Case of TJAU-MU Cooperative Education
}

\author{
Yunfei Ma \\ College of Humanities and Social Sciences, Tianjin Agricultural University, Tianjin, China \\ Email: esther054000@163.com
}

How to cite this paper: Ma, Y.F. (2019) Research on Talent Internationalization Cultivation Mode of Agricultural Universities-Illustrated by the Case of TJAU-MU Cooperative Education. Open Journal of Social Sciences, 7, 96-104.

https://doi.org/10.4236/jss.2019.710009

Received: September 3, 2019

Accepted: October 14, 2019

Published: October 17, 2019

\begin{abstract}
In the new period, China has issued a series of policies to encourage and constantly standardize the multi-level and wide-ranging Sino-foreign educational cooperation and exchanges, which is conducive to promoting the internationalization of education and personnel cultivation. Based on this, Tianjin Agricultural University adapted to the new situation, continuously expanding foreign exchanges and cooperation, actively exploring the talent internationalization cultivation mode, and cooperated with Madonna University of the United States in the major of Human Resources Management. Through the analysis of the present situation of the talents internationalization cultivation and Sino-foreign educational cooperation in agricultural universities and the construction of the training objectives and modes of Tianjin Agricultural University, this paper studies the establishment of the Joint Programme Management Committee, the reform of traditional teaching modes, the construction of courses and the management of teaching and so on, and discusses the cultivation of internationalization applied talents in agricultural universities. The purpose of this study is to better serve the development of modern urban agriculture.
\end{abstract}

\section{Keywords}

Agricultural Universities, Talent Internationalization Cultivation, Mode Research, Tianjin Agricultural University

\section{Introduction}

In February 2016, the General Office of the Central Committee of the Commun- 
ist Party of China and the General Office of the State Council issued a number of opinions on how to do a good job of opening up education in the new period (hereinafter referred to as "opinions"). The Opinion has made a scientific overall design for Sino-foreign cooperation in running schools in the new period and even for the whole cause of education opening to the outside world. It is the first programmatic document to comprehensively guide the development of China's education opening to the outside world since the founding of New China. It is also a programmatic document guiding the future Sino-foreign cooperation in running schools. Marked by the introduction of the "opinions", Sino foreign cooperation in running schools has entered a new and critical period of development. These new changes are embodied in the new policy trends of strengthening top-level design, improving system, strengthening process supervision, strengthening Party building and strengthening theoretical support in Sino-foreign cooperation in running schools [1].

Tianjin's Medium and Long-term Education Reform and Development Plan Outline (2010-2020) also proposed that in order to adapt to the trend of economic globalization and the requirements of the development and opening up of Binhai New Area, schools should carry out multi-level and wide-ranging education opening to the outside world to improve the level of education internationalization in Tianjin. To train a group of internationalized talents who have international vision, are familiar with international rules and can participate in international affairs and international competition. Government and schools will actively create conditions for the establishment of model Sino-foreign cooperative schools and establish a number of Sino-foreign cooperative projects or exchange and cooperation platforms. Tianjin should actively expand the scale of international students and strive to become one of the important cities of International Education Exchange Center [2].

Tianjin Agricultural University takes serving modern urban agriculture as its own responsibility, actively adapts itself to the development needs of modern urban agriculture, pays attention to the internationalization of personnel training, actively expands international exchanges and cooperation, carries out Sino-foreign cooperation in running schools, and constantly improves the level of open running schools. More than 60 universities in more than 30 countries and regions, such as Germany, Ukraine, Philippines, Japan, Canada, Britain and the United States, have established friendly inter-school relations and exchanges and cooperation relations [3]. According to the approval of Tianjin Education Commission in June 2013 (Tianjin Education Commission Document [2013] No. 18) on the establishment of Sino-US cooperative Human Resources Management specialty higher vocational education projects, Tianjin Agricultural University has started to organize cooperative programs with Madonna University from America since September 2014, aiming to improve the students' comprehensive abilities to meet the international standards. A good platform has been built [4]. With the development of agricultural internationalization, China urgently needs a large number of agricultural talents with international vision 
and cross-cultural communication ability, who are familiar with and master the professional knowledge of internationalization and international practices. Therefore, how to cultivate students into high-level talents who are good at grasping opportunities and striving for initiative in the global competition, and how to build a better platform for students' comprehensive ability to reach the international level is an urgent problem to be solved.

\section{The Current Situation of Talent Internationalization Cultivation and Sino Foreign Cooperation in Running Schools in Agricultural Universities}

\subsection{Related Research on Agricultural Talent Internationalization Cultivation}

In the course of writing, the author searched the CNKI database and took "talent internationalization cultivation" as the key word. A total of 56 documents were retrieved. Only one document on the theme of "talent internationalization cultivation in agricultural universities" and no article on the theme of "agricultural talent internationalization cultivation were retrieved. Thus it can be seen that the domestic discussion is more about the talent internationalization cultivation, while the research on the agricultural talent internationalization cultivation has not been carried out systematically. The research on the talent internationalization cultivation mainly focuses on the following aspects:

The construction of talent internationalization cultivation mode: Ma Qiang, Song Xingang and Li Guangzheng put forward the construction of applied talent internationalization cultivation mode for navigation specialty, lay a solid foundation for the first grade, carrying out the professional theory + basic skills + vocational skills education for the second and third grade, and participating in the seagoing post-training and graduation design for the fourth grade. Develop the educational form of diploma education + vocational education, and construct the applied talent internationalization cultivation mode for navigation specialty [5]. Ma Hailong's analysis of the internationalization cultivation mode of hotel management talents in colleges and universities puts forward that "actively promote cooperation between universities and enterprises, and jointly run schools with relevant foreign universities, through cooperation to achieve resource sharing, give full play to their respective advantages, jointly discuss related matters in education and teaching, improve the quality of personnel training, and achieve a common goal between the two sides" [6]. Zhao Lindu's research on the internationalization cultivation mode of China's logistics talents puts forward the "inviting in and going out" training mode, which has trained a large number of excellent international teachers for the internationalization of China's higher education. In the two-way interactive process of "inviting in and going out", many aspects of international talent training concept, training objectives, training model, training mechanism and so on are gradually in line with the international standards, and gradually formed a training model with Chinese characteristics [7]. Research on the Ways and Strategies of Talent Internationa- 
lization cultivation; Zhang Fen and Zhang Xiaoqing's talent internationalization cultivation approaches for tourism English majors in higher vocational colleges include strict selection procedures, targeted training, strict standardized management, and agreement protection of rights and interests [8]. Huang Bin and Mao Meina proposed the internationalization cultivation approaches for business English talents in local polytechnics: internationalization of curriculum system, internationalization of teaching staff, internationalization of communicative competence, and internationalization of practical training [9]. Guo Yao put forward the internationalization training strategy of logistics talents in higher vocational colleges: attaching importance to the cultivation of students' foreign language communication ability, cultivating students' professional ability according to the international standards of professional talents, attaching importance to the cultivation of students' international quality, and attaching importance to the development of students' international sense of integration [10].

\subsection{A Typical Case Study of Sino Foreign Cooperative Education in Agricultural Universities}

Nowadays, the development of international talents cultivation projects in domestic agricultural universities is not balanced. Some agricultural universities are in the initial and exploratory stage, and have not yet formed a scale and system. Some of them started early, and have achieved good results. Through the related literature survey, the following items can be drawn from:

The International College of Beijing Agricultural University has always been committed to international cooperation in the field of higher education, striving to explore and utilize foreign high-quality educational resources, following the development of world higher education in the context of economic globalization, advocating cross-cultural education, and building a higher education environment and platform for international talent cultivation. The " $3+1$ " education project of Harper Adams University has gone through the process from learning, drawing lessons from and operating the British education model to digesting, absorbing and reforming the domestic specialties and education model. It is moving towards integration in the collision, forming characteristics in the exploration and gaining achievements in the innovation, which is better for our use and more conducive to the growth of talents [11]. China Agricultural University adopts a full English teaching mode. For example, in Sino US University of Colorado cooperation project, $75 \%$ of the courses offered by the University of Colorado are taught in China by the teachers of the University of Colorado of the United States. The curriculum, teaching methods, assessment criteria, teaching materials and so on are all in line with the corresponding specialties of the University of Colorado. All the credits obtained are accepted by other American universities. The teaching environment, the teaching content and teaching mode are American-style. From the project graduates' application skills, communication skills and language skills have greatly improved [12]. The cooperative program between Shandong Agricultural University and Royal Agricultural 
University of England has realized the optimal allocation of teaching resources. The goal and program of personnel training are closely related to the needs of international industry. It enables students not only to master professional knowledge, but also to have an international perspective, and provides students with a smooth and stable way to go abroad for further study [13].

\section{The Construction of Training Objectives and Mode for TJAU-MU Cooperative Education in Human Resources Management Major}

\subsection{Objectives}

In order for students to meet the social development needs and to hold job in the field of human resource management and development or personnel management in corporations or government departments, this project, which mainly aims at all-around development of students, focus on fostering higher applied talents of management with solid basic theoretical knowledge and practical ability in management, economics and human resource management.

\subsection{Requirements}

The project requires students to learn and master basic theory and basic knowledge in management, economics and human resource management. During the study students should be trained to master basic methods and skills on human resource management, and their basic ability to analyze and solve the HR-related problems should be fostered as well.

Graduates from this project should process following knowledge and abilities:

1) Master basic theory and basic knowledge in management, economics and human resource management;

2) Master quantitative and qualitative analysis methods on human resource management;

3) Have strong ability in language, literacy, communication, organization and coordination, and leadership;

4) Familiar with guidelines, policies and regulation relevant to human resource management;

5) Understand theory and development trends relevant to the major they study, and understand the development trends of human resource management happened in rural areas;

6) Master basic measures in document retrieval and data query, have certain ability in scientific research and in practical work.

\subsection{Training Mode}

On the basis of mutual recognition of credits between Tianjin Agricultural College and Madonna University, the two universities have formulated a unified personnel training program. After completing all the courses and passing the American Foreign Language Examination, the students will continue to study at 
Madonna University for one year. After completing the follow-up courses prescribed by Madonna University, they will receive a bachelor's degree from the Madonna University. After obtaining a bachelor's degree, students can continue to pursue their master's degree in Madonna University. In order to stimulate students' initiative to study independently, Tianjin Agricultural University campus network provides students with rich and colorful learning materials. American teachers can also provide distance education and guidance to Chinese students through the network. Small class teaching, interactive teaching, using lecture, negotiation, discussion, games and other classroom teaching methods, fully mobilize the enthusiasm and initiative of students. For this major total credits required are 105 and thus total class hours required are $1854 \mathrm{~h}$. Madonna University appoints foreign teachers to undertake 12 core professional courses.

\section{Suggestions on Talent Internationalization Cultivation Mode for TJAU-MU Cooperative Education in Human Resources Management Major}

\subsection{Establishment of an International College}

International colleges should have a clear goal orientation for the talent internationalization cultivation in agricultural universities, do a good job in teaching and daily management of students, establish various channels for studying abroad to establish the foundation and guarantee, and provide better service for the internationalization of local agriculture. Administrators of international colleges should employ persons with overseas study and working background who have participated in Sino-foreign cooperation in running schools or exchanges; they can also employ school leaders, some parents' representatives, regional entrepreneurs' representatives and senior experts from the educational sector as advisors to the college. The International College should constantly improve the internationalization training mode of Tianjin Agricultural University. At the same time, it should regularly review the personnel training plan and teaching plan, so as to point out the direction for the development of internationalization talents of Tianjin Agricultural College, and help the school to expand international cooperation and exchanges, focusing on the internationalization development of Tianjin Agriculture. In order to meet the needs of international talents in agriculture, International College should actively introduce high-quality resources from overseas to carry out effective cooperation [14].

\subsection{Organic Integration of Language Teaching and Subject Education}

English teaching plays a very important role in Sino-foreign cooperative school-running projects, which is different from other common courses. Taking TJAU-MU Cooperative Education as an example, the students enrolled by Tianjin Agricultural University are majored in human resource management. Students study in Tianjin Agricultural University for three years and then can con- 
tinue to study at Madonna University for two years. Students can be awarded the undergraduate diploma if they meet the academic level requirements of Madonna University. Professional courses at Tianjin Agricultural University are taught in English by foreign teachers from Madonna University. In order to complete the professional courses, students need to read a large number of English original professional materials and books, discuss professional issues with teachers and students in class, and complete all assignments in English, and write the final thesis in English. In addition, all the related issues involved in the learning process, such as credit status, teaching plan, curriculum schedule and examination schedule, assessment requirements, etc., are presented in English as a carrier, and problems concerning learning are often communicated with foreign teachers through the Internet, such as handing in homework, curriculum consultation and so on. Therefore, students' English language proficiency has a direct impact on classroom activities, classroom attendance, after-class information access, teacher-student exchanges, and curriculum tasks and so on, thus playing a decisive role in students' professional development [15].

To break the traditional mode of taking natural classes as teaching units, students should take proficiency tests before starting language courses, and combine their English scores in the college entrance examination to classify students according to their language abilities, recognize individual differences, and implement graded teaching with a maximum of 20 students in each class. Teach students according to their aptitude and adopt different teaching materials. After a semester, students with improved grades can enter higher classes and students with poor grades enter lower grades, so as to arouse students' enthusiasm for learning and ensure that students at different levels can make maximum progress and improve their English level. In terms of curriculum design, increase the amount of English classes, freshmen have eight English classes a week that are twice as many as non-English majors'. And the curriculum refers to the curriculum of English majors, which is more detailed than that of non-English majors. It is divided into reading and vocabulary, writing and grammar, listening and speaking, so as to enable students to accept more professional, comprehensive and systematic language training to prepare for the professional courses offered by foreign teachers in sophomores.

In the selection of teaching materials, teachers will select the original English reading articles, listening and video materials related to human resources management and design oral practice tasks, conduct role-playing or situational simulation exercises, so that students can get in touch with the real context and corpus of their major as soon as possible, triggering students' professional interest. With the organic integration of language teaching and subject education, relying on the real corpus of the major, closely linking language and professional knowledge, integrating students' objective needs and immediate needs, timely adjusting teaching and assessment methods, supplemented by scientific guidance and innovative self-learning activities, students can get language support 
for learning their major. This teaching mode can not only improve students' autonomous learning ability, cultivate students' critical thinking and academic research ability, but also ensure that students master professional language knowledge skillfully while learning and consolidating professional knowledge, and finally acquire certain professional English communicative competence and academic research ability, so as to achieve seamless connection at home and abroad [15].

\section{Conclusion}

The relevant research on the agricultural talent internationalization cultivation is not enough. Combining with the talent internationalization cultivation in some agricultural universities, this paper discusses the training objectives and modes of TJAU-MU Cooperative Education in Human Resources Management Major and puts forward some suggestions on the talent internationalization cultivation mode. The talent internationalization cultivation in agricultural-related colleges and universities in China is still in its initial stage, which needs to be further deepened. International exchanges and cooperation should be continuously strengthened to adapt to the development of agricultural globalization.

\section{Acknowledgements}

This research was financially supported by Scientific Research Projects of Tianjin Municipal Education Commission: "Research on the Training Strategy of Talents Internationalization in Agricultural Universities under the Context of Modern Urban Agriculture” (2018SK116). China Agricultural Association funded project: "research on the strategy of universities agricultural think tank construction from the international perspective" (PCE1401).

\section{Conflicts of Interest}

The author declares no conflicts of interest regarding the publication of this paper.

\section{References}

[1] http://www.jyb.cn/china/gnsd/201701/t20170104 69234 3.html

[2] https://wenku.baidu.com/view/5ded27244b35eefdc8d33338.html?pn=50

[3] http://www.tjac.edu.cn/xxgk/xxij.htm

[4] http://gjil.tjau.edu.cn/info/1014/1465.htm

[5] Ma, Q., Song, X.G., Li, G.Z., Zhang, A.X. and Wang, T. (2013) Construction of Internationalization Training Mode for Applied Talents of Navigation Specialty. Research on Navigation Education, 4, 21-24.

[6] Ma, H.L. (2017) A Comparative Analysis of the Internationalization Training Mode of Hotel Management Talents in Ningxia Universities. Journal of Beifang University of Nationalities (Philosophy and Social Sciences Edition), 3, 73-76.

[7] Zhao, L.D. (2009) Research on International Training Mode of Chinese Logistics qualified Personnel. Logistics Education, 11, 265-267. 
[8] Zhang, F. and Zhang, X.Q. (2013) The Study and Practice on the Training for Internationalized Talents of Tourism English Majors in High Vocational Colleges: Case on Overseas Practice by Xinjiang Agricultural Vocational Technical College. Journal of Xinjiang Vocational University, 1, 13-21.

[9] Huang, B. and Mao, M.N. (2018) The Cultivation of International Business English Talents in Local Universities of Technology under the Background of "The Belt and Road": Taking Chongqing University of Technology as an Example. Journal of Chifeng University (Soc. Sci), 3,145-148.

[10] Guo, Y. (2018) Research on Training Strategies of Logistics Talents' Internationalization Ability in Higher Vocational Colleges from the Perspective of "Made in China”. E-Business Journal, 2, 64-65.

[11] http://www.gx211.com/news/20170913/n15052915178794.html

[12] http://edu.chinaso.com/detail/20160111/1000200032896341449821867873453468 1. $\underline{\mathrm{html}}$

[13] http://www.qqje.com/q/2018nsdnydxzyhzbxspzlyaqzysdnydxzyyhjxyjyghinydxji 42 93/

[14] Lu, W.J. (2018) Research on the Internationalization Training Model of Applied Talents: A Case Study of the International Course on Financial Management Jointly Organized by Hubei Normal University and Huailiqi Institute of Technology, New Zealand. Journal of Hubei Normal University (Philosophy and Social Sciences Edition), 1, 153-156.

[15] Jiao, L.J. and Chen, Y. (2018) A Study on the Teaching Model of Academic English in Sino-Foreign Cooperative Schools with the Integration of Language and Discipline. Journal of Social Science of Jiamusi University, 4, 188-191. 